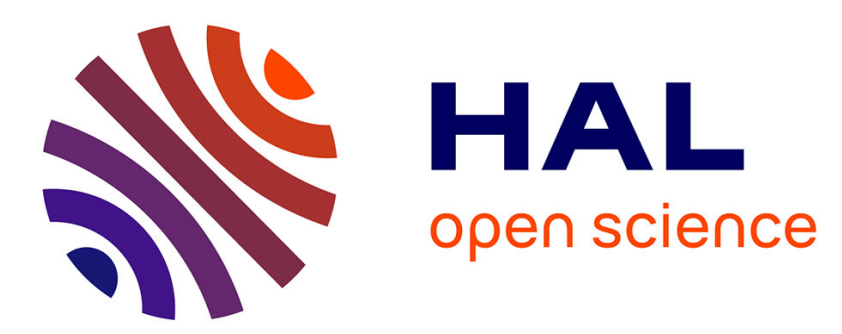

\title{
Additive or non-additive effect of mixing oak in pine stands on soil properties depends on the tree species in Mediterranean forests
}

Caroline Brunel, Raphaël Gros, Fabio Ziarelli, Anne Marie Farnet da Silva

\section{To cite this version:}

Caroline Brunel, Raphaël Gros, Fabio Ziarelli, Anne Marie Farnet da Silva. Additive or non-additive effect of mixing oak in pine stands on soil properties depends on the tree species in Mediterranean forests. Science of the Total Environment, 2017, 590-591, pp.676 - 685. 10.1016/j.scitotenv.2017.03.023 . hal01783101

\section{HAL Id: hal-01783101 \\ https: / hal-amu.archives-ouvertes.fr/hal-01783101}

Submitted on 2 May 2018

HAL is a multi-disciplinary open access archive for the deposit and dissemination of scientific research documents, whether they are published or not. The documents may come from teaching and research institutions in France or abroad, or from public or private research centers.
L'archive ouverte pluridisciplinaire HAL, est destinée au dépôt et à la diffusion de documents scientifiques de niveau recherche, publiés ou non, émanant des établissements d'enseignement et de recherche français ou étrangers, des laboratoires publics ou privés. 


\title{
Additive or non-additive effect of mixing oak in pine stands on soil properties depends on the tree species in Mediterranean forests
}

\author{
Caroline Brunel ${ }^{\mathrm{a}}$, Raphael Gros ${ }^{\mathrm{a}}$, Fabio Ziarelli ${ }^{\mathrm{b}}$, Anne Marie Farnet Da Silva ${ }^{\mathrm{a}, *}$

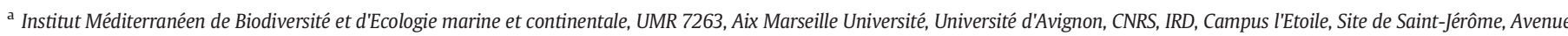 \\ escadrille Normandie-Niemen, 13397 Marseille Cedex 20, France \\ b Aix Marseille Université, CNRS, Spectropole Campus St Jérôme, Fédération des Sciences Chimiques de Marseille, FR 1739, 13397, Marseille, France
}

\section{H I G H L I G H T S}

- In litter, aromatic compounds decrease with high $\mathrm{OBA} \%$, promoting microbial growth.

- Oak abundance favored microbial diversity and biomass in topsoils for both stands.

- The holm oak print was linked to cutin.

- Non-additive effect on soil properties was found under $Q$. pubescens and $P$. sylvestris.

Keywords:

Mediterranean forests

Mixed forests

Non-additive effects

Organic matter quality

Soil horizons

\section{G R A P H I C A L A B S T R A C T}

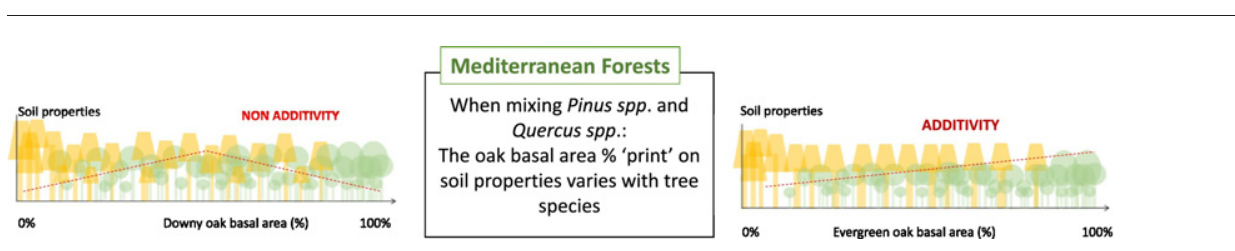

\begin{abstract}
A B S T R A C T
This study investigated how oak abundance in pine stands (using relative Oak Basal Area \%, OBA\%) may modulate soil microbial functioning. Forests were composed of sclerophyllous species i.e. Quercus ilex mixed with Pinus halepensis Miller or of $Q$. pubescens mixed with P. sylvestris. We used a series of plots with OBA\% ranging from 0 to $100 \%$ in the two types of stand $(n=60)$ and both OLF and A-horizon compartments were analysed. Relations between $\mathrm{OBA} \%$ and either soil chemical ( $\mathrm{C}$ and $\mathrm{N}$ contents, quality of organic matter via solid-state NMR, $\mathrm{pH}$, $\mathrm{CaCO}_{3}$ ) or microbial (enzyme activities, basal respiration, biomass and catabolic diversity via BIOLOG) characteristics were described. OBA\% increase led to a decrease in the recalcitrant fraction of organic matter (OM) in OLF and promoted microbial growth. Catabolic profiles of microbial communities from A-horizon were significantly modulated in $Q$. ilex and $P$. halepensis stand by OBA\% and alkyl $C$ to carboxyl $C$ ratio (characteristic of cutin from $Q$. ilex tissues) and in Q. pubescens and P. sylvestris stands, by OBA\% and $\mathrm{pH}$. In A-horizon under $Q$. ilex and $P$. halepensis stands, linear regressions were found between catabolic diversity, microbial biomass and OBA\% suggesting an additive effect. Conversely, in A-horizon Q. pubescens and P. sylvestris stands, the relationship between OBA\% and either cellulase activities, polysaccharides or ammonium contents, suggested a non-additive effect of Q. pubescens and P. sylvestris, enhancing mineralization of the OM labile fraction for plots characterized by an OBA\% ranging from $40 \%$ to $60 \%$. Mixing oak with pine thus favored microbial dynamics in both type of stands though OBA\% print varied with tree species and consequently sustainable soil functioning depend strongly on the composition of mixed stands. Our study indeed revealed that, when evaluating the benefits of forest mixed stand on soil microbial functioning and OM turnover, the identity of tree species has to be considered.
\end{abstract}

(c) 2017 Elsevier B.V. All rights reserved.

\footnotetext{
* Corresponding author.

E-mail address: anne-marie.farnet@imbe.fr (A.M. Farnet Da Silva).
}

\section{Introduction}

The dynamics of Mediterranean forest stands is subject to various environmental drivers acting at different spatio-temporal scales. Land use legacy and specific edaphic and climate conditions (geological 
substratum, soils poor in organic matter, intense summer drought) play an important role. The surface and composition of European Mediterranean forests were strongly structured by wildfires and human activities leading to agro-sylvo-pastoral systems during the last century (Quézel and Médail, 2004). From the 1930s on, abandonment of land previously devoted to agriculture and increasingly frequent wildfires promoted massive colonization of natural spaces by resinous species such as Pinus halepensis Mill. and Pinus sylvestris (Tatoni and Roche, 1994), resulting in pure stands. Yet mixed forests have long been considered essential to sustainable forestry management (Gartner and Cardon, 2004; Rodriguez-Loinaz et al., 2008). Biodiversity creates more varied habitats (Lust et al., 1998), produces more above-ground biomass (Vilà et al., 2007) and enhances resilience to stress and to disturbances like diseases (Pautasso et al., 2005), fires (Wirth, 2005) or extreme weather events (Dhôte, 2005). However, in Mediterranean areas, few studies have explored the relationship between above-ground tree species composition and both soil chemical and microbial characteristics (Lucas-Borja et al., 2011).

Mixed forests are heterogeneous ecosystems composed of patches varying in their relative proportion of tree species. Broadleaved species can be considered as ameliorative species, increasing the easily-degradable nutrients in conifer stands and thus enhancing microbial metabolism (Polyakova and Billor, 2007). By contrast, the chemical identities of pine litters and root exudates induce lower rates of decomposition because of their lack of nutrients (Khiewtam and Ramakrishnan, 1993), high recalcitrant organic matter content (Van Wesemael and Veer, 1992), allelopathic compounds and soil acidification (Rousk et al., 2010). Moreover, mixed stand 'print' has been shown to vary according to the functional traits of the tree-species constituting the mixture (Prescott and Grayston, 2013). Changes in tree species identity can actually modify both the biomass and the structure of soil microbial communities (Laganière et al., 2009; Matos et al., 2010). Thus, in mixed stands, these subtle variations in organic matter (OM) input can lead to additive or non-additive (synergistic or antagonistic) effects, modifying C and N dynamics (Scheibe et al., 2015). Overall, although the positive effect of mixed stands on the dynamics of OM decomposition has been reported (Bonanomi et al., 2014; Cuchietti et al., 2014; Sariyildiz et al., 2005), no simple and predictable patterns are available for forest management (Poca et al., 2015; Tardif et al., 2014).

In this study, we investigated the influence of oak occurrence on soil microbial functioning in pine stands, using an oak abundance gradient (assessed via Oak Basal Area percentage, OBA \%). We hypothesized that, in Mediterranean forests, oak abundance favors soil carbon dynamics via more labile and more diversified organic matter input. We focused on two types of mixed stands: Pinus halepensis Mill. and Quercus ilex and $P$. sylvestris and $Q$. pubescens. We assumed that the influence of the 'oak print' would vary with the Quercus species considered, since the evergreen $Q$. ilex and the deciduous $Q$. pubescens have species-specific chemical signatures and functional traits. Moreover, we investigated the effect of tree species relative composition on two soil compartments (OLF and A-horizon).

\section{Material and methods}

\subsection{Sampling strategy of A-horizon and across the gradient of admixture in} the two forests studied

The study was conducted in South Eastern France (Provence-Alpes Côte d'Azur), a region characterized by intense summer droughts and wet and temperate winters typical of Mediterranean climate. The Provence's soil is characterized by carbonatic pedofeatures, such as a fine calcareous silty clay loam. We conducted our study in two distinct zones in sub-humid (mean altitude: $400 \mathrm{~m}$, mean precipitations: $755 \mathrm{~mm}$ per year and mean air temperatures: $13.01{ }^{\circ} \mathrm{C}$, www.worldclim.org) and humid (mean altitude: $1000 \mathrm{~m}$, mean annual precipitations: $842 \mathrm{~mm}$ and air temperatures: $9.6{ }^{\circ} \mathrm{C}$, www.worldclim.org) bioclimates. Sclerophyllous forests of Quercus ilex mixed with Pinus halepensis are characteristics of the sub-humid climate while Quercus pubescens and Pinus sylvestris forests are found in the humid climate.

Sampling plots were selected in a $70 \mathrm{~km}^{2}$ area in either the Massif de la Sainte Baume $\left(43^{\circ} 21^{\prime} \mathrm{N}, 5^{\circ} 43^{\prime} \mathrm{E}\right)$ for the $Q$. ilex and $P$. halepensis stands (in the sub-humid climate) or in the Réserve Géologique of Digne les Bains ( $44^{\circ} 12^{\prime} \mathrm{N}, 5^{\circ} 59^{\prime} \mathrm{E}$ ) for the $Q$. pubescens and $P$. sylvestris stands (in the humid climate). For each area, a total of 30 circular plots of 0.02 ha with different relative basal areas of pine and oak (ranging from 0 to $100 \%$ of oaks in pine stands) were selected. The plots were chosen using the database of the Regional Center of Forest Property: mixed forest stands of $60 \pm 10$-year old, with similar north-facing slopes and soil type (calcaric Cambisol) and no sylvicultural practices for 30 years. For each plot, the numbers of stems found, stem density and basal area were measured and averages for each species are presented in Table 1.

The basal area of Quercus spp. and Pinus spp. (OBA and PBA respectively) of each sampling plot $\left(\mathrm{m}^{2} \cdot \mathrm{ha}^{-1}\right)$ was determined from each tree diameter measured at $1.20 \mathrm{~m}$ from the ground. The relative Oak Basal Area \% (OBA\%) was calculated as follows: $O B A \%=\frac{\sum(O B A)}{\sum(O B A+P B A)} \times 1$ 00

Sampling was performed in the first two weeks of October 2013. Within each plot, two sets of ten samples were collected in two soil compartments: the forest floor (OLF) and the surface mineral soil horizon from 0 to $15 \mathrm{~cm}$ depth (A-horizon). In each plot, set of 10 randomly chosen samples were pooled per horizons and each set of samples were pooled and sieved ( $2 \mathrm{~cm}$ and $2 \mathrm{~mm}$ mesh respectively for OLF and A-horizon). Soil samples were stored at $4{ }^{\circ} \mathrm{C}$ before the determination of microbial activities.

\subsection{Microbial community structure, respiration and enzymatic activities}

The microbial communities' catabolic profiles were compared with BIOLOG® Ecoplates (BIOLOG Inc., Hayward, CA) according to (Garland and Mills, 1991). $3 \mathrm{~g}$ of OLF or $5 \mathrm{~g}$ of A-horizon sample (dry weight equivalent) were shaken in $100 \mathrm{ml}$ sterile $0.1 \%$ sodium pyrophosphate ( $\mathrm{pH}$ 7.0) for $2 \mathrm{~h}$. The bacterial suspension was centrifuged at lowspeed run $(500 \mathrm{~g})$ for $6 \mathrm{~min}$. After further dilution in $0.85 \% \mathrm{NaCl}$, a 1 / 50 dilution was used to inoculate a series of 32 wells ( 1251 per well). The plates were incubated for up to 5 days at $25^{\circ} \mathrm{C}$ and the color development was recorded using a microplate reader (Infinite Tecan) at $590 \mathrm{~nm}$ twice a day. Microbial response in each microplate that expressed average well-color development (AWCD) was determined as follows: $A W C D=\frac{\sum O D i}{31}$ where $O_{\mathrm{i}}$ is optical density value from each well, corrected subtracting the blank well (inoculated, but without a carbon source) values from each plate well. The Shannon-Weaver index was calculated as follows: $H=-\sum p i\left(\right.$ Inpi) where $\mathrm{p}_{\mathrm{i}}$ is the ratio of the $O D$ on each substrate $\left(\mathrm{OD}_{\mathrm{i}}\right)$ to the sum of $\mathrm{OD}$ on all substrates $\sum \mathrm{OD}_{\mathrm{i}}$.

Microbial biomass (MB) was estimated using Substrate-Induced Respiration (SIR) according to Anderson and Domsch, 1978. Ten grams (dry weight equivalent) of standardized samples at $60 \%$ of WHC were placed in $117 \mathrm{ml}$ air flushed glass jars and amended with a mix powder of talc and glucose $\left(1000 \mu \mathrm{g} \mathrm{C} \mathrm{g}{ }^{-1}\right.$ soil). After $90 \mathrm{~min}$, $1 \mathrm{ml}$ of air was sampled with a syringe and injected into a gas chromatograph (Chrompack CHROM 3 - CP 9001) to determine $\mathrm{CO}_{2}$ production. The $\mathrm{CO}_{2}$ concentration of flushed air was subtracted from $\mathrm{CO}_{2}$ concentrations of each samples and resulting values were adjusted to $22^{\circ} \mathrm{C}$ according to Ideal Gas Laws using a $\mathrm{Q}_{10}=2$. SIR rates were converted into MB using equations given by (Beare et al., 1990). Basal respiration was estimated using the same method to calculate the metabolic quotient $q \mathrm{CO}_{2}$ (the ratio of basal respiration to microbial biomass), which is a sensitive ecophysiological indicator of soil stress induced by environmental conditions (Anderson, 2003). 


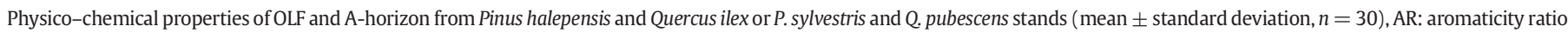
Results from Student $t$-test are shown, n.d.: not determined.

\begin{tabular}{|c|c|c|c|c|c|c|}
\hline & \multicolumn{2}{|l|}{ Effect of stand } & \multicolumn{2}{|c|}{ Pinus halepensis and Quercus ilex } & \multicolumn{2}{|c|}{$\begin{array}{l}\text { Pinus sylvestris and Quercus } \\
\text { pubescens }\end{array}$} \\
\hline & $t$-Test result in OLF & $t$-Test result in A-horizon & OLF & A-horizon & OLF & A-horizon \\
\hline \% alkyl C & ns & ns & $22.38 \pm 0.92$ & $24.11 \pm 1.02$ & $22.83 \pm 0.70$ & $23.98 \pm 1.42$ \\
\hline \% O-alkyl C & ns & $p<0.0001$ & $55.68 \pm 2.25$ & $45.77 \pm 0.96$ & $54.07 \pm 0.83$ & $49.18 \pm 1.68$ \\
\hline \% carboxyl C & $p<0.0001$ & $p<0.0005$ & $7.31 \pm 0.62$ & $10.7 \pm 1.01$ & $5.98 \pm 0.52$ & $8.77 \pm 0.97$ \\
\hline$\%$ aromatic C & ns & $p<0.05$ & $16.89 \pm 2.50$ & $19.38 \pm 1.29$ & $17.64 \pm 0.65$ & $18.06 \pm 1.11$ \\
\hline AR & ns & $p<0.01$ & $0.181 \pm 0.02$ & $0.217 \pm 0.13$ & $0.186 \pm 0.00$ & $0.198 \pm 0.01$ \\
\hline Alkyl C to Carboxyl C & $p<0.005$ & $p<0.0005$ & $3.23 \pm 0.51$ & $2.32 \pm 0.22$ & $3.91 \pm 0.32$ & $2.83 \pm 0.3$ \\
\hline Alkyl C to O-Alkyl C & ns & ns & $0.420 \pm 0.02$ & $0.528 \pm 0.02$ & $0.423 \pm 0.02$ & $0.492 \pm 0.04$ \\
\hline$\% \mathrm{~N}$ & $p<0.0001$ & $p<0.01$ & $1.13 \pm 0.12$ & $0.746 \pm 0.16$ & $0.814 \pm 0.10$ & $0.533 \pm 0.10$ \\
\hline$\% \mathrm{C}_{\text {organic }}$ & $p<0.005$ & $p<0.0001$ & $39.26 \pm 1.95$ & $15.80 \pm 4.80$ & $35.62 \pm 3.11$ & $9.73 \pm 4.91$ \\
\hline $\mathrm{C}: \mathrm{N}$ & $p<0.0001$ & $p<0.0005$ & $36.09 \pm 3.59$ & $22.44 \pm 2.00$ & $45.1 \pm 3.79$ & $18.1 \pm 2.15$ \\
\hline $\mathrm{NH}_{4}^{+}(\mathrm{nmol})$ & $p<0.0005$ & $p<0.0001$ & $1.07 \pm 0.25$ & $1.81 \pm 0.73$ & $0.689 \pm 0.12$ & $7.79 \pm 2.68$ \\
\hline$\% \mathrm{CaCO}_{3}$ & n.d. & $p<0.05$ & - \pm- & $12.68 \pm 2.50$ & - \pm- & $35.86 \pm 10.92$ \\
\hline $\mathrm{pH} \mathrm{KCl}$ & $p<0.05$ & ns & $5.28 \pm 0.01$ & $6.61 \pm 0.34$ & $5 . \overline{43} \pm 0.01$ & $6.76 \pm 0.25$ \\
\hline $\mathrm{pH} \mathrm{H} \mathrm{H}_{2} \mathrm{O}$ & ns & $p<0.05$ & $5.43 \pm 0.13$ & $6.84 \pm 0.17$ & $5.55 \pm 0.12$ & $7.00 \pm 0.14$ \\
\hline
\end{tabular}

In order to describe the functional capacity of the microbial community, the activity of five extracellular enzymes (EEA) involved in soil organic matter recycling were assessed: phenoloxidase, cellulase, lipase, protease and urease. Activities are reported as $\mu \mathrm{mol}$ of reaction product. $\mathrm{g}$ dry weight ${ }^{-1} \mathrm{~h}^{-1}\left(\mathrm{U} \mathrm{g}^{-1} \mathrm{DW}\right)$. All the experiments were performed in triplicate for each soil sample.

Phenoloxidase activity was assessed according to the modified method of Saiya-Cork et al. (2002). 2 ml of 25 mM L-DOPA solution (L3,4-dihydroxyphenylalanine) in potassium phosphate buffer $(50 \mathrm{mM}$, $\mathrm{pH}$ 6.5) were added to $0.5 \mathrm{~g}$ of A-horizon soil / $0.3 \mathrm{~g}$ of OLF (fresh mass), mixed and incubated for $30 \mathrm{~min}$, in darkness at $25^{\circ} \mathrm{C}$. The mixture was centrifuged $3 \mathrm{~min}$ at $12000 \mathrm{~g}$ before measuring absorption at $590 \mathrm{~nm}$.

Cellulase activity was assayed using CarboxyMethylCellulose (CMC) at $1 \%$ as substrate with $2 \mathrm{ml}$ of sodium acetate buffer ( $50 \mathrm{mM}, \mathrm{pH} 6)$ added to $0.5 \mathrm{~g}$ of A-horizon soil / $0.3 \mathrm{~g}$ of OLF (fresh mass), mixed and incubated for $4 \mathrm{~h}$ at $50{ }^{\circ} \mathrm{C}$. The reducing sugars released were quantified according to Somogyi-Nelson method, the mixture was centrifuged $2 \mathrm{~min}$ at $12000 \mathrm{~g}$, then $1 \mathrm{ml}$ of the supernatant with $1 \mathrm{ml}$ of Somogyi reagent were boiled $15 \mathrm{~min}$ at $100^{\circ} \mathrm{C}$. Once cooled, the mixture was added to $1 \mathrm{ml}$ of the Nelson reagent. After a last centrifugation (2 min, $12,000 \mathrm{~g}$ ), the mixture absorption was measured at $870 \mathrm{~nm}$ (Farnet et al., 2010).

Transesterase activity of lipase was assessed according to the method of Goujard et al. (2009). $2 \mathrm{ml}$ of distilled water and $4 \mathrm{ml}$ of $10 \mathrm{mM} p$ nitrophenyl-caprylate in heptane were added to $5 \mathrm{~g}$ of A-horizon soil/ $3 \mathrm{~g}$ of OLF (fresh mass) and incubated for $24 \mathrm{~h}$ at $30^{\circ} \mathrm{C}$. The reaction was stopped and color revealed by adding $200 \mu$ of the mixture to $4 \mathrm{ml}$ of $0.1 \mathrm{M} \mathrm{NaOH}$, which was immediately centrifuged for $2 \mathrm{~min}$ at $12,000 \mathrm{~g}$. The amount of $p$-nitrophenol released was measured at $412 \mathrm{~nm}$.

Protease activity was measured using $5 \mathrm{~g}$ of A-horizon soil/3 $\mathrm{g}$ of OLF (fresh weight) in $5 \mathrm{ml}$ of casein at $2 \%$ in Tris $\mathrm{HCl}$ buffer $(50 \mathrm{mM}, \mathrm{pH} 8.1$ ). The mixture was incubated for $3 \mathrm{~h}$ at $50{ }^{\circ} \mathrm{C}$ and then the reaction was stopped with $5 \mathrm{ml}$ of Trichloroacetic acid solution (at 15\%) and the mixture centrifuged ( $2 \mathrm{~min}, 12,000 \mathrm{~g}$ ). Aromatic amino acids were detected using Folin reagent (33\%) at $700 \mathrm{~nm}$ (Ladd and Butler, 1972). Tyrosine was used as standard.

Urease activity was assessed using $0.5 \mathrm{~g}$ of A-horizon soil / $0.3 \mathrm{~g}$ of OLF (fresh weight) in $2 \mathrm{ml}$ of urea solution $(80 \mathrm{mM})$ in a sodium acetate buffer ( $50 \mathrm{mM}, \mathrm{pH} 6)$. The mixture was incubated for $2 \mathrm{~h}$ at $37^{\circ} \mathrm{C}$ and then centrifuged ( $2 \mathrm{~min}, 12,000 \mathrm{~g}$ ). Ammonium was revealed in microplates using an adapted Mulvaney method (1996): $15 \mu$ of EDTA solution, $60 \mu \mathrm{l}$ of $\mathrm{Na}$-salicylate solution and $30 \mu \mathrm{l}$ of hypochlorite solution were added to $30 \mu \mathrm{l}$ of the supernatant. After stabilization ( $45 \mathrm{~min}$ ), mixture absorption was measured at $667 \mathrm{~nm}$.

\subsection{Soil physical and chemical analyses}

Total $\mathrm{C}$ and $\mathrm{N}$ contents were measured using a C/N elementary analyser (Flash EA 1112 serie ThermoScientific) on the dried cylindrical soil-core fraction $<2 \mathrm{~mm}$. $\mathrm{pH}_{2} \mathrm{O}$ and $\mathrm{pH} \mathrm{KCl}$ was determined in distilled water or $1 \mathrm{M} \mathrm{KCl}$ after 45 min under magnetic stirring at $600 \mathrm{rpm}$. Determination of calcium carbonate $\left(\mathrm{CaCO}_{3}\right)$ in A-horizon samples is based on the volumetric analysis of the carbon dioxide $\mathrm{CO}_{2}$, which is released during the application of hydrochloric acid solution $\mathrm{HCl} 4 \mathrm{~N}$ and was performed using calcimeter Bernard modified method. Carbon proportion of $\mathrm{CaCO}_{3}$ was then calculated using the molar mass: $\% \mathrm{C}-\mathrm{CaCO}=\frac{11.991}{100} \times \% \mathrm{CaCO} 3$. Then organic carbon was calculated by the difference between total $\mathrm{C}$ content and $\mathrm{C}$ $\mathrm{CaCO}_{3}$ content.

A subsample of $6 \mathrm{~g}$ OLF or $10 \mathrm{~g}$ A-horizon (dry weight equivalent) was analysed after extraction in $100 \mathrm{ml}$ of $1 \mathrm{M} \mathrm{KCl}$ with an ammonium electrode to determine inorganic-N concentration in soils. Another subsample of $10 \mathrm{~g}$ was incubated for 30 days at $25^{\circ} \mathrm{C}$ and maintained at initial moisture and the same method was used to determine net ammonification and nitrification. We defined ammonification and nitrification rates as the difference in concentration before and after incubation.

The solid state ${ }^{13} \mathrm{C}$ NMR spectra were obtained on a Bruker Avance $400 \mathrm{MHz}$ NMR spectrometer operating at a ${ }^{13} \mathrm{C}$ resonance frequency of $106 \mathrm{MHz}$ and a Bruker double-bearing probe. $80 \mathrm{mg}$ of dry grinded soil were placed in a zirconium dioxide rotor of $4 \mathrm{~mm}$ outer diameter and spun at a magic angle spinning (MAS) rate of $10 \mathrm{kHz}$. The cross polarization (CP) technique (Schaefer and Stejskal, 1976) was applied with a ramped $1 \mathrm{H}$-pulse starting at $100 \%$ power and decreasing until $50 \%$ during the contact time (i.e. $2 \mathrm{~ms}$ ) in order to circumvent Hartmanne Hahn mismatches (Cook et al., 1996; Peersen et al., 1993). To improve the resolution, a dipolar decoupling GT8 pulse sequence (Gerbaud et al., 2003) was applied during the acquisition time. To obtain a good signal to-noise ratio in ${ }^{13} \mathrm{C}$ CPMAS experiment, 12,000 scans were accumulated using a delay of $2.5 \mathrm{~s}$. The ${ }^{13} \mathrm{C}$ chemical shifts were referenced to tetramethylsilane (at $0 \mathrm{ppm}$ ) and calibrated with glycine carboxyl signal set at $176.5 \mathrm{ppm}$. An integration of each spectrum was performed using Dmfit software (Massiot et al., 2002) to determine the relative intensity of each chemical region. The ${ }^{13} \mathrm{C}$ $\mathrm{CP} / \mathrm{MAS}$ NMR spectra were divided according to Mathers and $\mathrm{Xu}$ (2003) into 4 chemical shift regions: Alkyl C (0-45 ppm, lipids, cutin and suberin), O-alkyl C (45-112 ppm, carbohydrates, cellulose, hemicellulose and methoxy l C), aromatic C (112-160 ppm, lignin, tannin, olefins and aromatic compounds) and carboxyl C (160-185 ppm, carboxylic acid, amide and ketone groups). To describe the organic matter quality, the following ratio of humification (HR), aromaticity ( $\mathrm{Ar}$ ) were 
calculated according to Baldock and Preston (1995):

$$
\begin{aligned}
& \mathrm{HR}_{1}=\operatorname{alkyl} \mathrm{C} / \text { carboxyl C } \\
& \mathrm{HR}_{2}=\operatorname{alkyl~C/O}-\text { alkyl C } \\
& \mathrm{Ar}=\operatorname{aromatic} \mathrm{C} /(\text { alkyl C }+\mathrm{O}-\text { alkyl C }+ \text { aromatic } \mathrm{C})
\end{aligned}
$$

Within each of the sampled plots, 4 cylindrical core samples were taken with PVC cylinders of $98.125 \mathrm{~cm} 3(5 \mathrm{~cm}$ diameter, $5 \mathrm{~cm}$ height) to determine bulk density, carbon (C) and nitrogen (N) stocks. Bulk densities ( $\rho \mathrm{b}$ in $\mathrm{g} \mathrm{cm}^{-3}$ ) were determined by weighing fraction $<2 \mathrm{~mm}$ of $90^{\circ} \mathrm{C}$-dried samples (Blake and Hartge, 1986).

\subsection{Data analyses}

Differences in chemical and microbial characteristics of OLF and Ahorizon between both types of stands were determined using Student's $t$-test after normality and homoscedasticity controls and transformation when necessary.

Relationships between OBA\% and the chemical characteristics (NMR data, C\%, N\%) on one hand and microbiological characteristics (AWCD and $\mathrm{H}^{\prime}$ from Biolog data, $5 \mathrm{EEA}, \mathrm{BR}, \mathrm{MB}$ ) on the other hand were analysed by linear, quadratic and piecewise regression models using stat and segmented packages from R software. Significant models $(p<0.05)$, with the lowest Akaike Information Criterionvalues are considered as best-fit (Burnham and Anderson, 2002). When piecewise regression was the best-fits, the segmented function calculated an optimum breakpoint (i.e. with the smallest interval of confidence).

We assessed non-additivity or additive effect of stand mixture on the soil markers studied. To do so, we calculated predicted averages based on the respective monospecific stands (pure pine is considered from 0 to $20 \%$ OBA and pure oak from 80 to $100 \%$ OBA). Samples were gathered by ranges, from [20-40\% OBA], from [40-60\% OBA], and from [60-80\% OBA]. The relative non-additive effect (NAE\%) can be calculated by the ratio: [(observed-predicted) / predicted] $* 100$. Each NAE\% obtained by ranges was tested by one-side Student's $t$-test. If this ratio differs significantly from 0 , it would indicate non-additive (synergistic or antagonistic) effect of the mixture on stocks.

To determine more precisely whether OBA\% influence OLF and Ahorizon catabolic profiles, a PERMANOVA was performed using 999 permutations. According to our results and to test how certain chemical characteristics and OBA\% influence catabolic diversity for each bioclimate, unconstrained distance-based redundancy analyses (dbRDA) were performed on catabolic profiles from A horizon. Their significance was tested by a Monte Carlo permutation test using 999 permutations.

All statistical analyses when performed using R software (3.2.1, R Development Core team, 2015), levels of significance are indicated as $p \leq 0.05$.

\section{Results}

\subsection{Differences in soil chemical and microbial characteristics of OLF and A- horizon depending on the type of stand}

We first investigated how soil characteristics may be differently shaped in the two types of stand (Pinus halepensis and Quercus ilex vs $P$. sylvestris and $Q$. pubescens), and whether this may further differ according to soil compartment, i.e. forest floor (OLF) and mineral topsoil (A-horizon). Soil organic matter (in both OLF and A-horizon) under Pinus halepensis and Quercus ilex was characterized by larger amounts of total $\mathrm{N}$ and organic $\mathrm{C}$, (Table 1 ). However, these varying chemical properties did not induce changes in microbial biomass, BR and $q \mathrm{CO}_{2}$ (Fig. 1). Catabolic diversity (Shannon-Weaver index, $\mathrm{H}^{\prime}$ ) and $\mathrm{C}: \mathrm{N}$ ratio followed opposite trends: a high $\mathrm{H}^{\prime}$ was always associated with a low C:N ratio. The patterns differed according to type of stand and soil compartment: $\mathrm{H}^{\prime}$ was higher (and C: $\mathrm{N}$ ratio lower) in OLF under P. halepensis and Q. ilex stands, while the opposite trend was observed in A-horizon.

In OLF, a lower alkyl $\mathrm{C}$ to carboxyl $\mathrm{C}$ ratio (short-chain acids), lower $\mathrm{C}$ : $\mathrm{N}$ ratio and higher ammonium content (Table 1 ), together with a stronger microbial potential (higher AWCD, $\mathrm{H}^{\prime}$, lipase, protease and phenoloxidase activities as shown in Fig. 1), were found under Pinus halepensis and Quercus ilex than under P. sylvestris and $Q$. pubescens.

By contrast, in A-horizon, organic matter was less recalcitrant under $P$. sylvestris and $Q$. pubescens, with a higher content in polysaccharides (higher O-alkyl C signal), lower aromaticity ratio, C: $\mathrm{N}$ ratio and higher ammonium content. Moreover $\mathrm{pH}$, known to be a major physico-chemical driver of microbial communities, was higher in A-horizon of P. sylvestris and Q. pubescens stands (this may be related to the higher $\mathrm{CaCO}_{3}$ content in soils). These physico-chemical properties probably promote highly efficient microbial functioning, since both $\mathrm{H}^{\prime}$, cellulase and AWCD were significantly higher in Ahorizon of these stands. Our findings indicate that the P. halepensis and $Q$. ilex 'prints' induced favorable chemical properties and thus higher microbial activities in the OLF, while the P. sylvestris and Q. pubescens 'print' produced similar favorable conditions in the mineral topsoil.

\subsection{Differences in organic matter quality and microbial properties across an Oak Basal Area \% (OBA\%) gradient}

Linear, segmented and polynomial relations between OBA\% and soil parameters were tested. Linear (Table 2, Fig. 2) and segmented relations (Fig. 3) were the most significant models based on the AIC criterion. The influence of OBA\% on chemical and microbial soil markers showed different patterns in the two types of stand.

In OLF of Quercus ilex and Pinus halepensis stands, linear regressions were found for all the NMR chemical markers describing organic matter quality (Table 2). This result is noteworthy, suggesting that the effects of the two species on these soil chemical properties are additive. Increase in OBA\% led to more labile carbon resources such as polysaccharides (O-Alkyl C $p<0.01, r=0.445$ ) and to more intense humification characterized by the production of acids with shorter chains. This is supported by the decrease in alkyl $C$ to carboxyl $C$ ratio across the OBA\% gradient $(p<0.001, r=-0.490)$. On the other hand, the NMR chemical regions associated with the recalcitrant fraction of organic matter, i.e. lignin (aromatic C) and lipids (alkyl C), were negatively correlated with OBA\% $(p<0.01, r=-0.462$ for aromatic $C$ and $p<0.05, r=-0.367$ for alkyl C). Interestingly, the OBA\% effect revealed in the OLF of Quercus ilex and Pinus halepensis stands by NMR markers was not found in the A-horizon. Increased relative abundance of Quercus ilex in pine stands led to a decrease in C: N ratio in this compartment $(p<0.001, r=-0.524)$.

In the OLF of $Q$. pubescens and $P$. sylvestris stands, increased $Q$. pubescens relative abundance also led to less recalcitrant organic matter, as shown by two NMR markers (aromatic C, $p<0.001, r=-0.509$ and alkyl $C$ to carboxyl $C$ ratio, $p<0.001, r=-0.439$ ). Interestingly, when we examined the A-horizon, we found non-linear but segmented relations for O-alkyl $\mathrm{C}$ assigned to polysaccharides, which is likely associated with the oak 'print' (Fig. $3 \mathrm{~A}$ ). O-alkyl C significantly decreased from 0 to $49 \%$ OBA and then slowly increased from 49 to $100 \%$ OBA $(r=0.59, p<0.001)$.

Linear correlations between microbial markers and OBA\% are shown in Fig. 2. For Quercus ilex and Pinus halepensis stands, no correlation was significant in OLF (Fig. $2 \mathrm{~A}, \mathrm{C}$ and $\mathrm{E}$ ), but the mineral topsoil showed increased microbial biomass (Fig. $2 \mathrm{~B}$ ) and functional diversity (Fig. 2 F) across the OBA\% gradient $(p<0.05, r=0.370$ and $p<0.05$, 

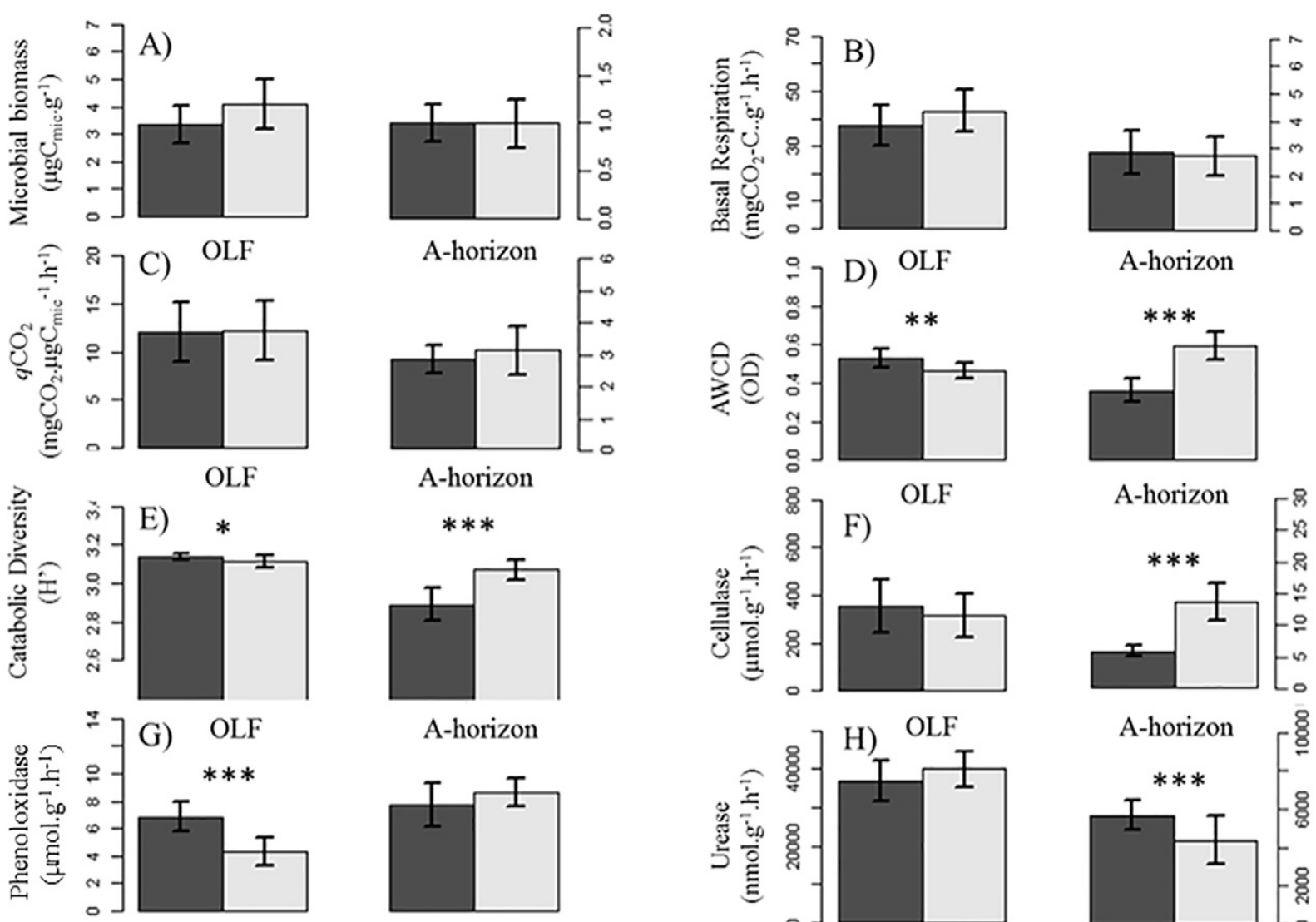

A-horizon
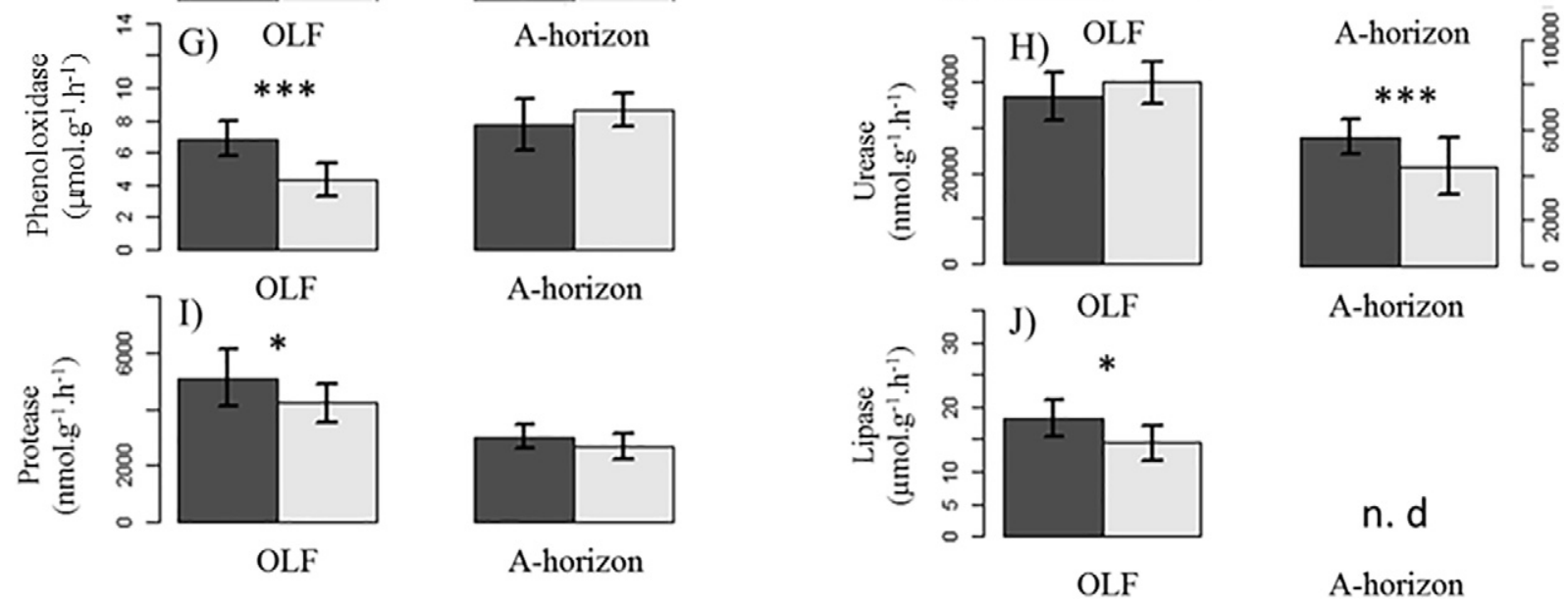

A-horizon

n. $d$

\section{A-horizon}

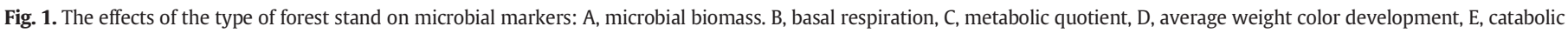

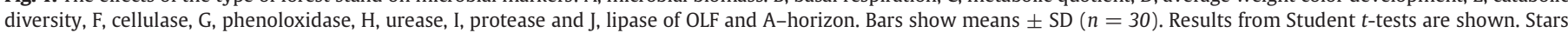

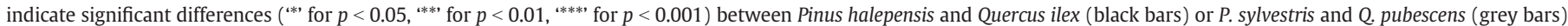
stands in each compartment treated separately. n.d. means not determined.

$r=0.364$, respectively). OBA\% was also positively correlated with microbial biomass in the mineral topsoil of $Q$. pubescens and P. sylvestris stands (Fig. 2 B, $p<0.001, r=0.602$ ). Moreover, a segmented

Table 2

Linear-correlation coefficient between Oak Basal Area \% (OBA\%) and soil physico-chemical parameters according to the soil compartment and the stand considered $(n=30)$. Pearson correlation results are indicated by ns for $p>0.05,\left({ }^{*}\right)$ for $p<0.05$, $\left({ }^{* *}\right)$ for $p<0.01$, or $\left({ }^{* * *}\right)$ for $p<0.001$.

\begin{tabular}{|c|c|c|c|c|}
\hline & \multicolumn{2}{|c|}{$\begin{array}{l}\text { Pinus halepensis and } \\
\text { Quercus ilex }\end{array}$} & \multicolumn{2}{|c|}{$\begin{array}{l}\text { Pinus sylvestris and } \\
\text { Quercus pubescens }\end{array}$} \\
\hline & OLF & A-horizon & OLF & A-horizon \\
\hline \% alkyl C & $-0.367 *$ & ns & ns & ns \\
\hline \% O-alkyl C & $0.445^{* *}$ & ns & ns & ns \\
\hline \% carboxyl C & $0.525^{* * *}$ & $0.487^{* * *}$ & ns & $0.433^{* * *}$ \\
\hline$\%$ aromatic C & $-0.462^{* *}$ & ns & $-0.509^{* * *}$ & ns \\
\hline Alkyl C to carboxyl C & $-0.49^{* * *}$ & ns & $-0.439^{* * *}$ & ns \\
\hline Alkyl C to O-alkyl C & $-0.524^{* * *}$ & ns & ns & ns \\
\hline$\% \mathrm{~N}$ & ns & ns & ns & ns \\
\hline$\% \mathrm{C}$ & ns & ns & ns & ns \\
\hline $\mathrm{C}: \mathrm{N}$ & ns & $-0.524^{* * *}$ & ns & ns \\
\hline $\mathrm{NH}_{4}^{+}(\mathrm{nmol})$ & ns & ns & ns & ns \\
\hline $\mathrm{pH} \mathrm{KCl}$ & ns & ns & ns & $-0.419^{* * *}$ \\
\hline
\end{tabular}

correlation was observed for cellulase activity, which increased from 0 to $39 \%$ OBA and then decreased from 39\% to 100\% OBA (Fig. 3 B, $p<0.001, r=0.67)$. These activities were also correlated with the O-alkyl fraction $(r=-0.47, p<0.01)$, assigned to polysaccharides.

To assess how mixed forest stands modify soil properties, the non-additive effect (NAE) of species admixture was calculated for the chemical and microbial markers characterizing the $\mathrm{C}$ and $\mathrm{N}$ cycle, i.e. BR, cellulase, $\mathrm{MB}, \mathrm{C}$ and $\mathrm{N}$ content, $\mathrm{NH}_{4}^{+}$content (Fig. 4). In both types of stand, microbial biomass was the sole marker showing a synergistic non-additive effect $(+38.6 \%$ and $+27.4 \%$ respectively) of stand admixture for an OBA\% range of 40 to $60 \%$. In the OLF of $Q$. pubescens and $P$. sylvestris stands, this was associated with lower $\mathrm{N}$ content than that expected $(-23.1 \%)$. In the A-horizon of $Q$. ilex and $P$. halepensis stands, $C$ content showed synergistic non-additive effects $(+26.9)$ for an OBA\% range of 40 to $60 \%$, while microbial basal respiration was significantly lower $(-26.4 \%)$ than expected for the same OBA\% range. It was in the A-horizon of $Q$. pubescens and $P$. sylvestris stands that strong synergistic non-additive effects were found for $\mathrm{NH}_{4}^{+}$content $(+102.1 \%)$ and cellulase activities ( + $92.0 \%$ ), while additive effects were observed for the other markers, $\mathrm{MB}, \mathrm{BR}, \mathrm{C}$ and $\mathrm{N}$ content, as described above. 

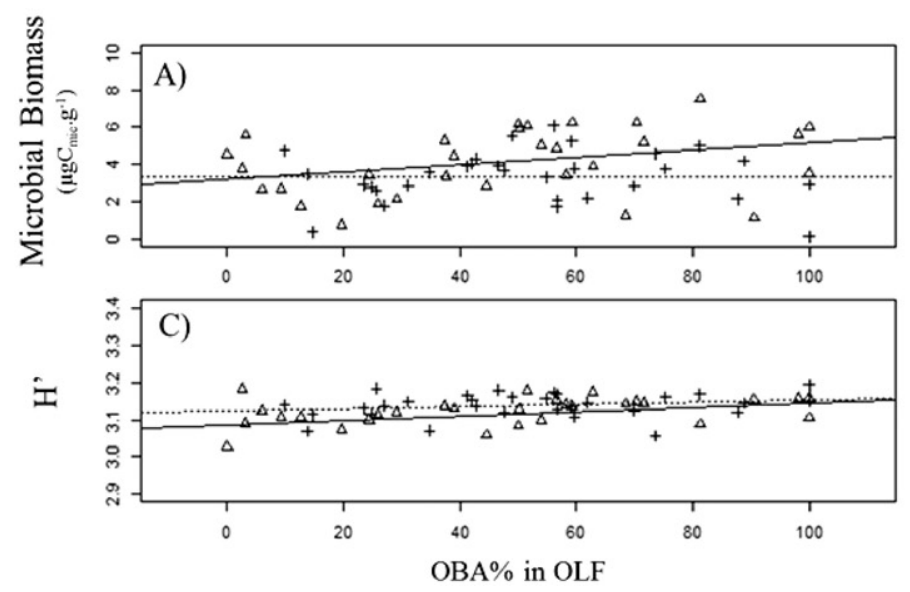
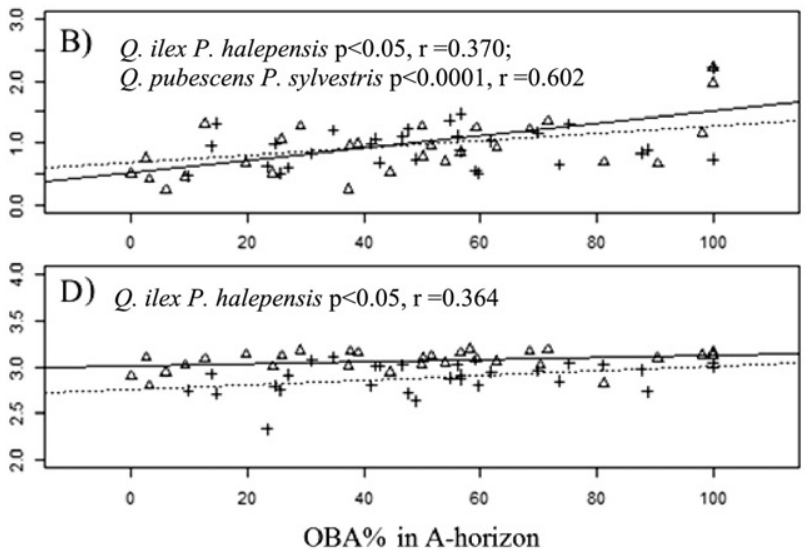

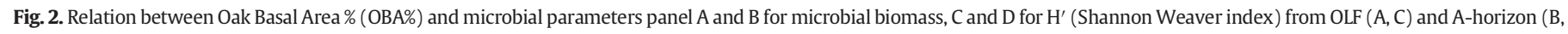

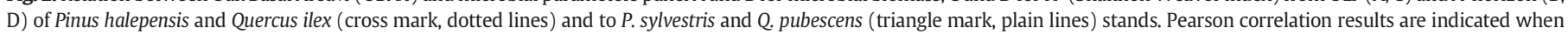
significant.

\subsection{Differences in catabolic profiles of A-horizon across an Oak Basal Area\% (OBA\%) gradient}

Redundancy analysis (dbRDA) was performed to investigate how catabolic profiles interact with chemical parameters and OBA\%. OBA\% had no significant effect on the catabolic profiles of microbial communities in OLF (PERMANOVA $p>0.05$ ), while a significant effect of relative oak abundance on catabolic profiles of microbial communities was found in A-horizon (PERMANOVA $p<0.01$ ). For $Q$. ilex and P. halepensis stands, the two first axes of the dbRDA ordination bi-plots explained $17.8 \%$ and $7.3 \%$ of the total variance in the A-horizon catabolic profile data (Fig. $5 \mathrm{~A}$ ). dbRDA highlighted the significant influence of the $\mathrm{OBA} \%$ gradient ( $p s e u d o-\mathrm{F}=3.73 p=0.002$ ), mainly discriminating between plots with the lowest (from 0 to $20 \%$ ) and the highest (from 80 to $100 \%$ ) OBA\% (respectively on the left and the right side of the dbRDA). $\mathrm{OBA} \%$ and recalcitrant organic matter (alkyl $\mathrm{C}$ to carboxyl $\mathrm{C}$ ratio)

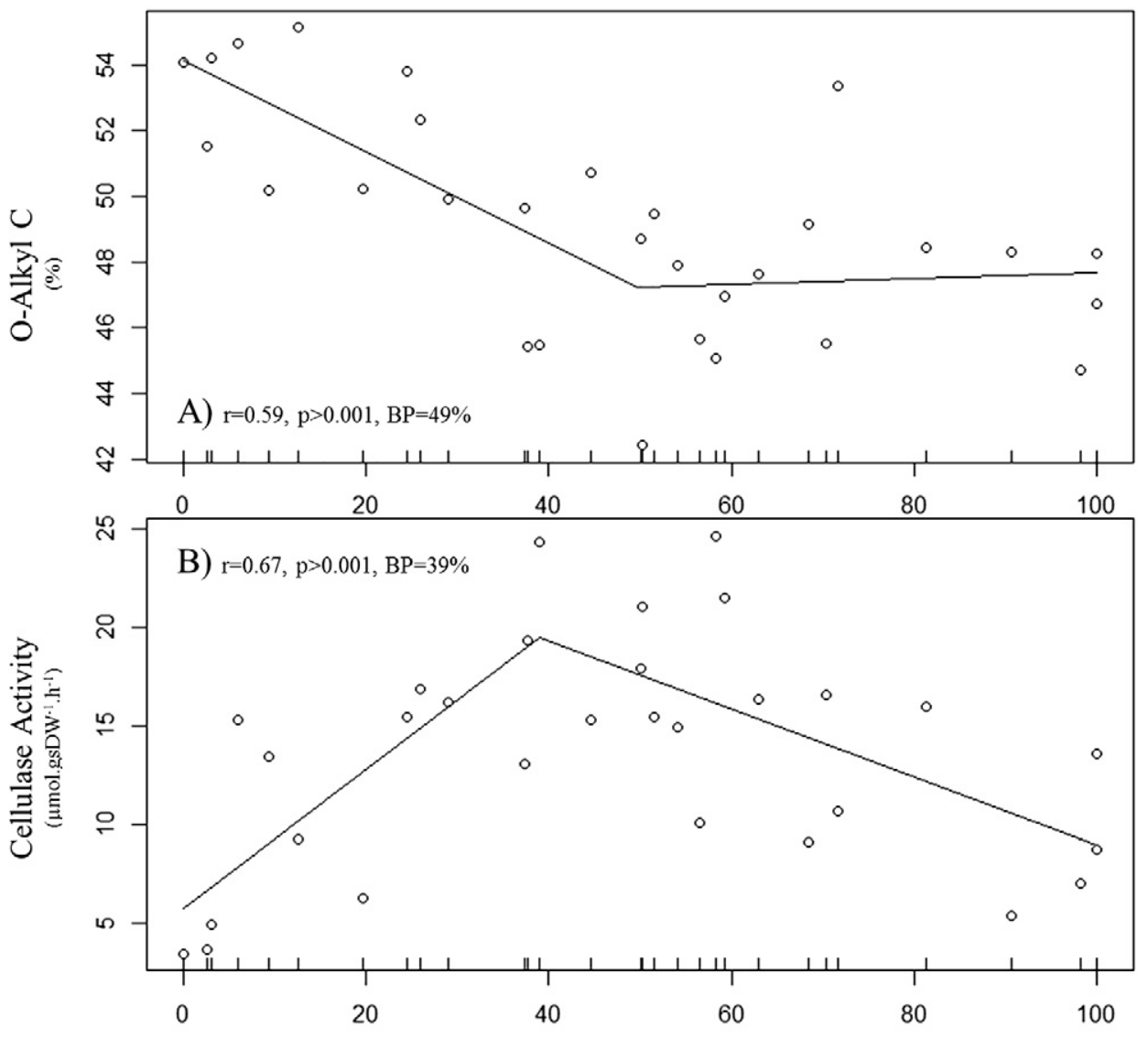

Oak Basal Area (\%)

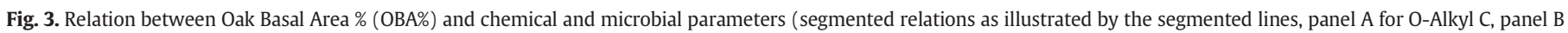
cellulase activity) in top mineral soil (A-horizon) of P. sylvestris and Q. pubescens stands. Piecewise correlation results are indicated. 

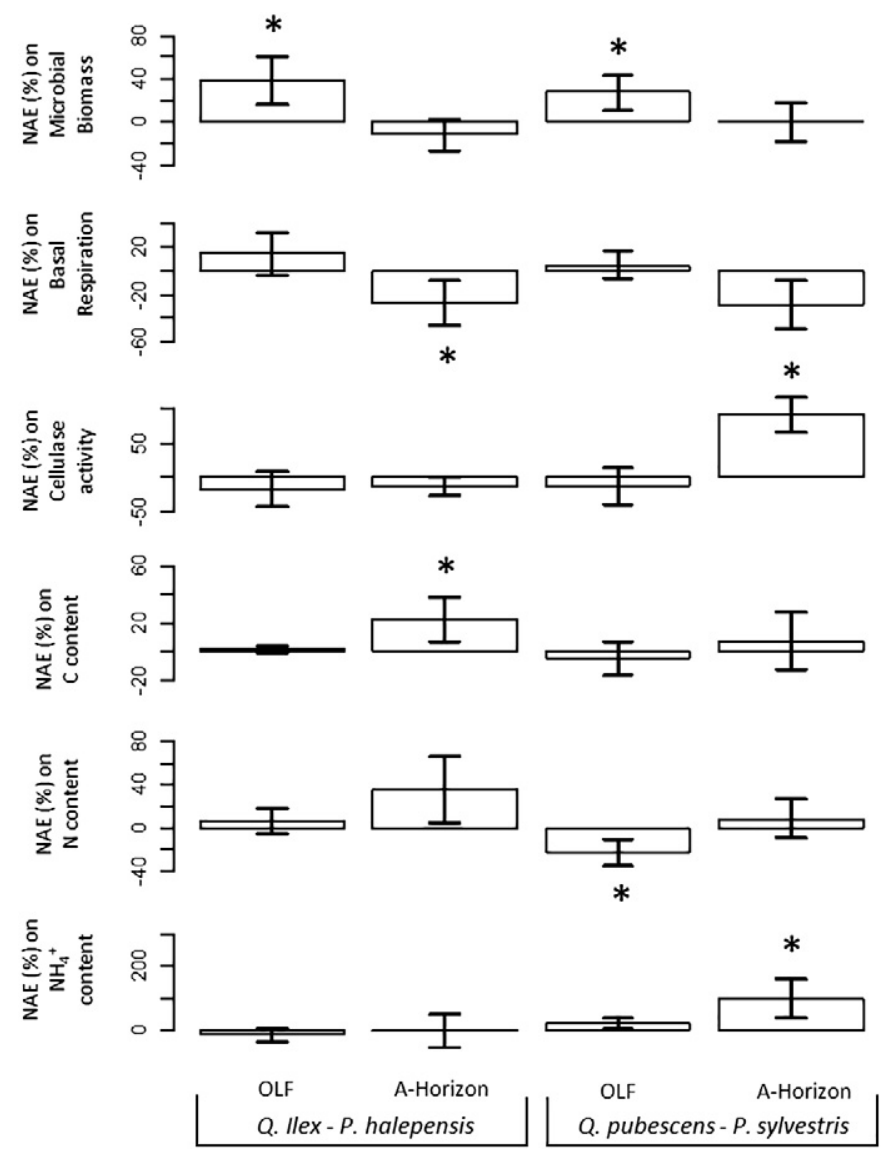

Fig. 4. Non-Additivity Effect (NAE) of Oak Basal Area \% (OBA\%) for range [40-60 OBA\%]. on microbial biomass, basal respiration, cellulase, $\mathrm{C}, \mathrm{N}$ and $\mathrm{NH}_{4}^{+}$content from OLF and Ahorizon in both Pinus halepensis and Quercus ilex and P. sylvestris and Q. pubescens stands. Non-additive effects (NAE) were calculated as $100 \times$ (observed-predicted) / predicted. [0-20 OBA\%] and [80-100 OBA\%] ranges were considered as monocultures and used as such in calculation. NAE significantly different from zero, according to onesample Student's $t$-test, are indicated by '*' for $p<0.05$, '**' for $p<0.01$, and ${ }^{~ * * * '}$ for $p<0.001$.

explained the catabolic profiles of plots with the highest relative oak abundance ( $p$ seudo- $\mathrm{F}=3.7 p=0.002$, pseudo- $\mathrm{F}=3.9 p=0.006$ ). Alkyl C content ( $p$ seudo- $\mathrm{F}=3.03 p=0.006$ ) and $\mathrm{pH} \mathrm{KCl}$ (pseudo- $\mathrm{F}=$ $2.37 p=0.029$ ) were the two chemical factors explaining projections for plots with OBA\% ranging from 25 to 70\%. Thus, in Q. ilex and $P$. halepensis stands, differences in catabolic profile were mainly observed between the extreme ranges of OBA\% (0 to $20 \%$ and 80 to $100 \%$ ), pointing to the importance of both $P$. halepensis ([0-20\% OBA]) and $Q$. ilex ([80-100\% OBA]) 'prints'.

For Q. pubescens and P. sylvestris stands (Fig. 5 B), dbRDA1 accounted for $14.1 \%$ and dbRDA2 for $5.1 \%$ of total variance. The catabolic profiles were structured according to $\mathrm{CaCO}_{3}$ content (pseudo- $\mathrm{F}=2.19 p=$ 0.045 ) and to $\mathrm{pH} \mathrm{KCl} \mathrm{(pseudo-F}=3.72 p=0.007$ ) and $\mathrm{OBA} \%$ was also a significant parameter separating microbial catabolic structures along dbRDA1 ( $p$ seudo-F $=2.2 p=0.042$ ), although this trend was not as strong as for the $Q$. ilex and P. halepensis stands.

\section{Discussion}

4.1. Soil microbial and chemical properties differ between the two types of stands

This study investigated how oak admixtures in pine stands influence microbial functioning of forest floor (OLF) and mineral topsoil (A- horizon), and whether this influence differs between the two types of stand considered ( $Q$. ilex and P. halepensis, Q. pubescens and P. sylvestris).

We found that soil properties were strongly modified by the composition of the stand: the Pinus halepensis and Quercus ilex stand 'print' appears to lead to favorable chemical properties and thus higher microbial activities in OLF, while P. sylvestris and Q. pubescens stands produced favorable conditions in the mineral topsoil. More precisely, A-horizon under $Q$. ilex and $P$. halepensis stands was characterized by higher amounts of $\mathrm{C}$ and $\mathrm{N}$ and acid $\mathrm{pH}$ than $\mathrm{A}$-horizon under $\mathrm{Q}$. pubescens and $P$. sylvestris, but the microbial markers (biomass, respiration, extracellular enzyme activities) did not vary. $Q$. ilex and $P$. halepensis stands were located in the Meso-Mediterranean climate area, characterized by more drastic climate conditions (drought events and heat waves, Pons and Quézel, 1998), and this may have limited the microbial activities involved in organic matter decomposition.

Differences in catabolic diversity were observed between the two types of stand, with a higher $\mathrm{H}^{\prime}$ index found in A-horizon of Q. pubescens and $P$. sylvestris stands in the humid climate. In a similar Mediterranean context, Pailler et al. (2014) reported the key role of climate and soil chemical properties on microbial communities' catabolic profiles at a regional scale. Moreover, Sherman and Steinberger (2012) reported differences in functional diversity, which was higher under a more humid climate within the Mediterranean area.

\subsection{The effect of OBA\% on soil properties differs with the soil compartment}

To understand the influence of oak abundance in pine stands, linear, quadratic and piecewise regression models were used to describe the relationship between OBA\% and the different soil variables studied. NAE was also calculated for each variable to reveal whether mixing oak and pine species had synergistic or antagonist effects on soil microbial and chemical properties. Although we assessed two different Quercus spp. here (evergreen vs broadleaves), certain physico-chemical and microbial markers were similarly influenced by oak abundance in both types of stand. In OLF, the admixture of either evergreen or deciduous oaks in pine stands led to a decrease in the proportion of recalcitrant organic matter, as previously described (Prescott and Grayston, 2013). This decrease in aromatic compounds has to be linked to the synergistic non-additive effects on microbial biomass found for range $[40-60 \%$ OBA $]$ in OLF. Thus, whatever the tree species, mixing oak and pines promoted microbial growth. Chapman et al. (2013) and Kominoski et al. (2007) also find that mixing litter of different species stimulates microbial biomass production: they suggest that microbial communities colonize mixed litter more rapidly due to the increased diversity of niches and substrates. Several studies (Hernández and Hobbie, 2010; Meier and Bowman, 2010) show that increasing the chemical diversity of litter is positively related to soil respiration rates; they describe these results as complementarity effects. Similarly, Chapman and Newman (2010), suggest that litter chemical diversity favors the coexistence of greater numbers of functional microorganisms in mixed litter, resulting in an enhanced production of microbial biomass.

In the mineral topsoil of both types of stand, microbial biomass increased linearly with OBA\%. This is noteworthy, since it indicates that the effects of OBA\% on microbial biomass differed with the soil horizon. This supports the results of Chapman et al. (2013) suggesting that mixing litter favors microbial colonization only at the early stages of decomposition. In the topsoil, the observed increase in microbial biomass with OBA\% may be connected to enhanced mineralization, as suggested by the increased carboxyl C content in A-horizon with OBA\%, whatever the type of stand. Accumulation of carboxyl groups is indeed often accompanied by a further, more complete humification leading to humic acids (Percival et al., 2000) and to oxidative cleavages of lignin sidechains producing aromatic structures containing carboxyl groups (Zech et al., 1992). 
A)

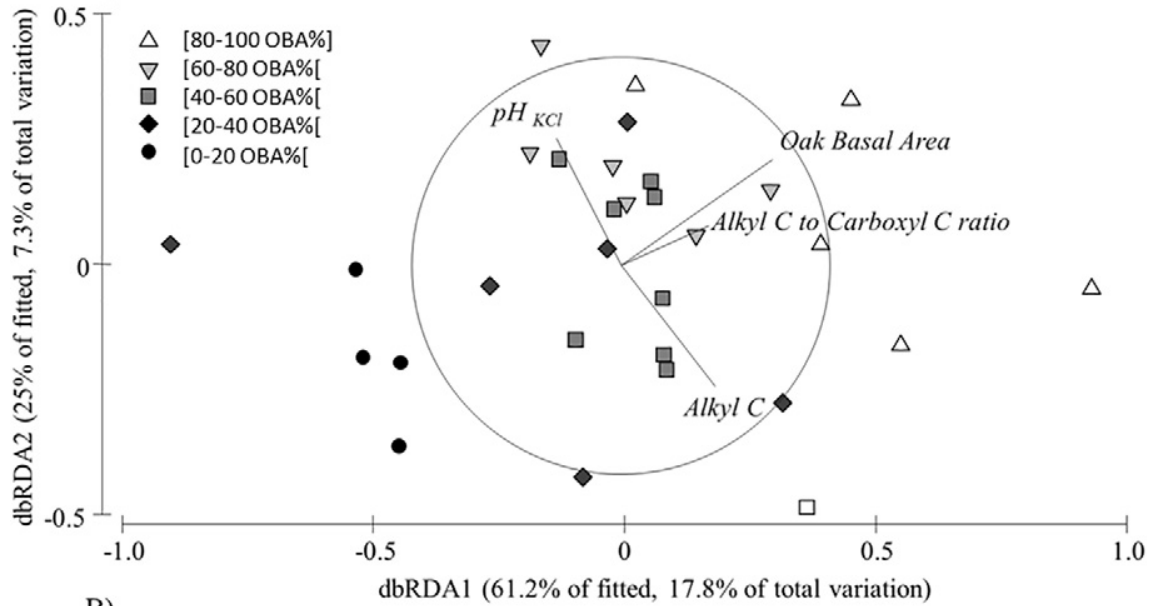

B)

dbRDA1 $(61.2 \%$ of fitted, $17.8 \%$ of total variation)

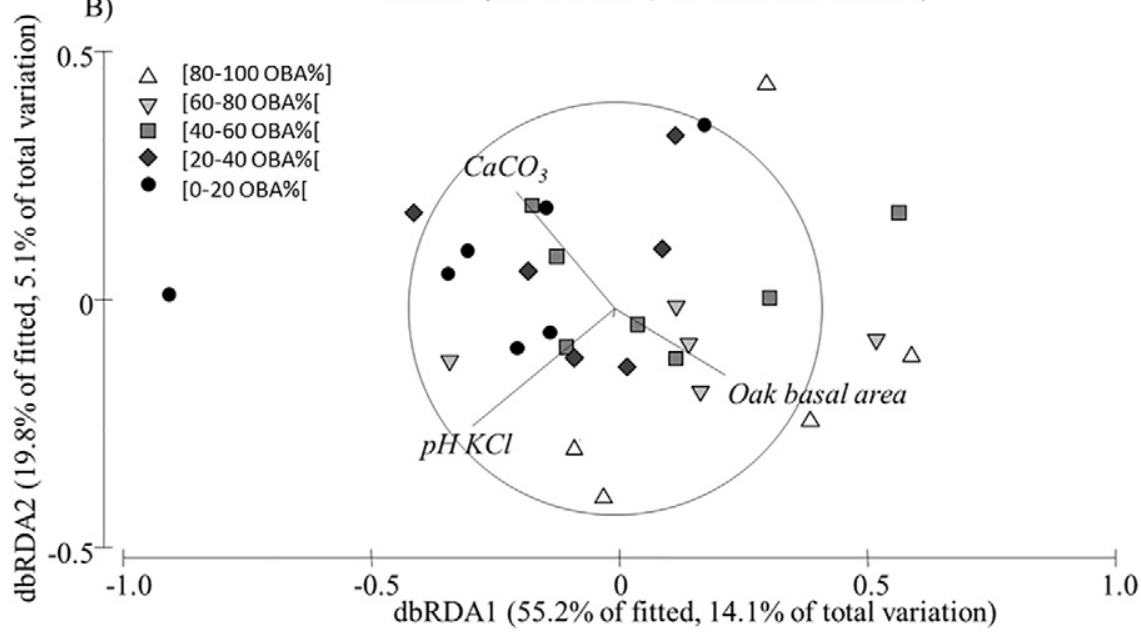

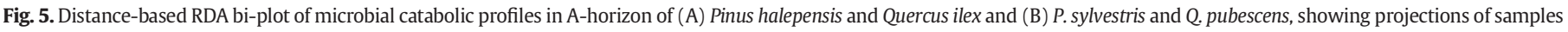
from different Oak Basal Area \% (OBA\%) ranges with various significant chemical properties as explanatory variables.

\subsection{The effect of $O B A \%$ on soil properties differs with the type of stand}

Our study also highlighted differences in soil properties between the two types of stand. In mineral topsoil under Q. ilex and P. halepensis, linear regressions were found between OBA\% and certain soil properties (higher microbial biomass and catabolic diversity), indicating an additive effect of mixing species. Previous findings (Liu et al., 2001; Polyakova and Billor, 2007) showed that nutrient diffusion is higher in oak-leaf litter than in pine-needle litter and that $\mathrm{N}$ concentration increases with oak relative abundance, favoring $C$ assimilation in the microbial biomass. Moreover, the positive effect of OBA\% on functional biodiversity is of major importance, since soil microbial diversity plays a key role in the sustainability of soil processes driven by enzyme activities (Jiang et al., 2011). Here, moreover, for range [40-60\% OBA] in Ahorizon, antagonist non-additive effects of mixing $Q$. ilex and $P$. halepensis were found for microbial basal respiration, together with a synergistic non-additive effect on $C$ content. This indicates that, in this type of stand, a balanced proportion of pines and oaks ([40-60\% OBA\%]) did not favor mineralization leading to an increase in soil C content. In topsoil under $Q$. pubescens and $P$. sylvestris, segmented regressions proved to be the best model to describe relationships between OBA\% and soil properties, revealing an intense degradation potential of cellulose at around 40\% OBA. Thus, the Q. pubescens and P. sylvestris admixture had a positive impact on this crucial activity involved in soil labile-C transformation. This fraction of organic matter is vital in regulating nutrient availability for plants and microbes (Haubensak et al., 2002; Xiao et al., 2015). The non-additive synergistic effects on ammonium content also revealed an enhanced potential for transformation of labile OM. Moreover, the fact that additive effects (and not synergistic effects) were found for microbial biomass or soil $\mathrm{C}$ and $\mathrm{N}$ content suggests that mixing $Q$. pubescens and $P$. sylvestris may induce $\mathrm{C}$ loss through $\mathrm{CO}_{2}$.

The effects of the admixture of Pinus spp. and Quercus spp. also differed with the type of stand for catabolic profiles of A-horizon. In $Q$. ilex and $P$. halepensis A-horizon, OBA\% and recalcitrant organic matter (alkyl C to carboxyl C ratio) explained the catabolic profiles, mainly discriminating range [80-100\% OBA] from the other projections. Alkyl C to carboxyl $C$ ratio is usually assigned to the lipid fraction of organic matter, which mainly relies on plant cutin, a particularly abundant polymer in Quercus ilex. Alkyl C to carboxyl C ratio was correlated with increasing $\mathrm{OBA} \%$, indicating that the recalcitrant organic matter of $Q$. ilex structured the catabolic profiles under $Q$. ilex and P. halepensis stands. Previous studies (Iovieno et al., 2010; Kara et al., 2008) pointed out the specific effects of tree species on soil microbial community structure through above- and below-ground soil inputs, which modify organic matter quality and quantity (recalcitrant fraction and $\mathrm{N}$ content). However, in the topsoil of $Q$. pubescens and $P$. sylvestris stands, OM quality did not stand out as the main factor structuring catabolic profiles. Interestingly, $\mathrm{CaCO}_{3}$ and $\mathrm{pH} \mathrm{KCl}\left(\mathrm{CaCO}_{3}\right.$ is known to strongly influence $\mathrm{pH}$, Römkens and Dolfing, 1998) appeared to be the main drivers of catabolic profiles, though this structuration was not as strong as that found under $P$. halepensis and $Q$. ilex stands. This is consistent with the higher quantity 
of $\mathrm{CaCO}_{3}$ in soils of $Q$. pubescens and P. sylvestris and with the linear correlation found between $\mathrm{pH} \mathrm{KCl}$ and $\mathrm{OBA} \%$ under these stands. Cesarz et al. (2013) showed that relatively weak variations in $\mathrm{pH}$ (0.2 pH units) probably linked to root exudates, can modify the structure of microbial community using PLFA. Rousk et al. (2010) found that soil microbial communities were strongly structured by $\mathrm{pH}$ across a gradient. Though the composition of both fungal and bacterial communities was affected by $\mathrm{pH}$, bacterial populations were more strongly influenced, while fungi were associated with low $\mathrm{pH}$, as commonly observed (Blagodatsky and Richter, 1998). This is consistent with the recent study of Scheibe et al. (2015), who found that $\mathrm{pH}$ was the major physicochemical parameter explaining PLFA profiles of soil microbial communities in a mixed broadleaved forest.

\section{Conclusion}

Tree species admixtures of oaks and pines can potentially maximize the diversity of nutrient resources and consequently favor microbial diversity, biomass and catabolic potential, through complementary ecological niches. Our study reveals that, when evaluating the benefits of mixed forest stands on soil microbial functioning, it is important to consider the functional group (deciduous, evergreen and conifer) the tree species belongs to. Our findings indicate that the OBA\% 'print' on soil microbial communities varies with tree species, and consequently sustainable soil functioning may depend strongly on the composition of mixed stands.

\section{Acknowledgments}

The project was financially supported by the French Environment and Energy Management Agency (ADEME) and the Provence Alpes Côte d'Azur Region (France).We are very grateful to W. Kima and O. Voluzan for their very helpful technical assistance and to Mrs M. Sweetko and Mr. P. Fournier who ensured the English of this article. We are grateful to the Regional Center of Forest Property (CRPF) for their contribution and especially to Mr. Olivier Martineau for his valuable recommendations in determining the selected sites.

\section{References}

Anderson, T.-H., 2003. Microbial eco-physiological indicators to asses soil quality. Agric. Ecosyst. Environ. 98:285-293. http://dx.doi.org/10.1016/S0167-8809(03)00088-4.

Anderson, J.P.E., Domsch, K.H., 1978. A physiological method for the quantitative measurement of microbial biomass in soils. Soil Biol. Biochem. 10, 215-221.

Baldock, J., Preston, C.M., 1995. Chemistry of Carbon Decomposition Processes in Forests as Revealed by Solid-state 13C NMR 89-117.

Beare, M.H., Neely, C.L., Coleman, D.C., Hargrove, W.L., 1990. A substrate-induced respiration (SIR) method for measurement of fungal and bacterial biomass on plant residues. Soil Biol. Biochem. 22:585-594. http://dx.doi.org/10.1016/00380717(90)90002-H.

Blagodatsky, S., Richter, O., 1998. Microbial growth in soil and nitrogen turnover: a theoretical model considering the activity state of microorganisms. Soil Biol. Biochem. 30, 1743-1755.

Blake, G.R., Hartge, K.H., 1986. Particle Density. Methods Soil Anal. Part 1-Physical Mineral. Methods. sssabookseries. :pp. 377-382 http://dx.doi.org/10.2136/sssabookser5.1. 2ed.c14.

Bonanomi, G., Capodilupo, M., Incerti, G., Mazzoleni, S., 2014. Nitrogen transfer in litter mixture enhances decomposition rate, temperature sensitivity, and C quality changes. Plant Soil 381:307-321. http://dx.doi.org/10.1007/s11104-014-2119-4.

Burnham, K.P., Anderson, D.R., 2002. Model Selection and Multimodel Inference: A Practical Information-Theoretic Approach. Springer Science \& Business Media.

Cesarz, S., Fender, A.C., Beyer, F., Valtanen, K., Pfeiffer, B., Gansert, D., Hertel, D., Polle, A., Daniel, R., Leuschner, C., Scheu, S., 2013. Roots from beech (Fagus sylvatica L.) and ash (Fraxinus excelsior L.) differentially affect soil microorganisms and carbon dynamics. Soil Biol. Biochemist 61, 23-32.

Chapman, S.K., Newman, G.S., 2010. Biodiversity at the plant-soil interface: microbial abundance and community structure respond to litter mixing. Oecologia 162: 763-769. http://dx.doi.org/10.1007/s00442-009-1498-3.

Chapman, S.K., Newman, G.S., Hart, S.C., Schweitzer, J.A., Koch, G.W., 2013. Leaf litter mixtures alter microbial community development: mechanisms for non-additive effects in litter decomposition. PLoS One 8:1-9. http://dx.doi.org/10.1371/journal.pone. 0062671.
Cook, R.L., Langford, C.H., Yamdagni, R., Preston, C.M., 1996. A modified cross-polarization magic angle spinning 13C NMR procedure for the study of humic materials. Anal. Chem. 68, 3979-3986.

Cuchietti, A., Marcotti, E., Gurvich, D.E., Cingolani, A.M., Pérez Harguindeguy, N., 2014. Leaf litter mixtures and neighbour effects: low-nitrogen and high-lignin species increase decomposition rate of high-nitrogen and low-lignin neighbours. Appl. Soil Ecol. 82: 44-51. http://dx.doi.org/10.1016/j.apsoil.2014.05.004.

Dhôte, J.-F., 2005. Implication of forest diversity in resistance to strong winds. In: SchererLorenzen, D.M., Körner, P.D.C., Schulze, P.D.E.-D. (Eds.), Forest Diversity and Function, Ecological Studies. Springer, Berlin Heidelberg, pp. 291-307.

Farnet, A.M., Qasemian, L., Guiral, D., Ferré, E., 2010. A modified method based on arsenomolybdate complex to quantify cellulase activities: Application to litters. Pedobiologia 53:159-160. http://dx.doi.org/10.1016/j.pedobi.2009.09.001.

Garland, J.L., Mills, A.L., 1991. Classification and characterization of heterotrophic microbial communities on the basis of patterns of community-level sole-carbon-source utilization. Appl. Environ. Microbiol. 57, 2351-2359.

Gartner, T.B., Cardon, Z.G., 2004. Decomposition dynamics in mixed-species leaf litter Oikos 104, 230-246.

Gerbaud, G., Ziarelli, F., Caldarelli, S., 2003. Increasing the robustness of heteronuclear decoupling in magic-angle sample spinning solid-state $\{$ NMR $\}$. Chem. Phys. Lett. 377:1-5. http://dx.doi.org/10.1016/S0009-2614(03)01056-X.

Goujard, L., Villeneuve, P., Barea, B., Lecomte, J., Pina, M., Claude, S., Le Petit, J., Ferré, E., 2009. A spectrophotometric transesterification-based assay for lipases in organic solvent. Anal. Biochem. 385, 161-167.

Haubensak, K.A., Hart, S.C., Stark, J.M., 2002. Influences of chloroform exposure time and soil water content on $\mathrm{C}$ and $\mathrm{N}$ release in forest soils. Soil Biol. Biochem. 34: 1549-1562. http://dx.doi.org/10.1016/S0038-0717(02)00124-4.

Hernández, D.L., Hobbie, S.E., 2010. The effects of substrate composition, quantity, and diversity on microbial activity. Plant Soil 335:397-411. http://dx.doi.org/10.1007/ s11104-010-0428-9.

Iovieno, P., Alfani, A., Bååth, E., 2010. Soil microbial community structure and biomass as affected by Pinus pinea plantation in two Mediterranean areas. Appl. Soil Ecol. 45: 56-63. http://dx.doi.org/10.1016/j.apsoil.2010.02.001.

Jiang, Y., Chen, C., Xu, Z., Liu, Y., 2011. Effects of single and mixed species forest ecosystems on diversity and function of soil microbial community in subtropical China. J. Soils Sediments 12:228-240. http://dx.doi.org/10.1007/s11368-011-0442-4.

Kara, Ö., Bolat, İ., Çakıroğlu, K., Öztürk, M., 2008. Plant canopy effects on litter accumulation and soil microbial biomass in two temperate forests. Biol. Fertil. Soils 45: 193-198. http://dx.doi.org/10.1007/s00374-008-0327-x.

Khiewtam, R., Ramakrishnan, P., 1993. Litter and fine root dynamics of a relict sacred grove forest at Cherrapunji in north-eastern India. For. Ecol. Manag. 60, 327-344.

Kominoski, J.S., Pringle, C.M., Ball, B.A., Bradford, M.A., Coleman, D.C., Hall, D.B., Hunter, M.D., 2007. Nonadditive effects of leaf litter species diversity on breakdown dynamics in a detritus-based stream. Ecology 88, 1167-1176.

Ladd, J., Butler, J., 1972. Short-term assays of soil proteolytic enzyme activities using proteins and dipeptide derivatives as substrates. Soil Biol. Biochem. 4, 19-30.

Laganière, J., Paré, D., Bradley, R.L., 2009. Linking the abundance of aspen with soil faunal communities and rates of belowground processes within single stands of mixed aspen-black spruce. Appl. Soil Ecol. 41, 19-28.

Liu, C.-J., Westman, C., Ilvesniemi, H., 2001. Matter and nutrient dynamics of pine (Pinus tabulaeformis) and oak (Quercus variabilis) litter in North China. Silva Fenn. 35 http://dx.doi.org/10.14214/sf.599.

Lucas-Borja, M.E., Candel, D., Jindo, K., Moreno, J.L., Andrés, M., Bastida, F., 2011. Soil microbial community structure and activity in monospecific and mixed forest stands, under Mediterranean humid conditions. Plant Soil 354:359-370. http://dx.doi.org/ 10.1007/s11104-011-1072-8.

Lust, N., Muys, B., Nachtergale, L., 1998. Increase of biodiversity in homogeneous Scots pine stands by an ecologically diversified management. Biodivers. Conserv. 7: 249-260. http://dx.doi.org/10.1023/A:1008892620387.

Massiot, D., Fayon, F., Capron, M., King, I., Le Calve, S., Alonso, B., Durand, J., Bujoli, B., Gan, Z., Hoatson, G., 2002. Modelling one-and two-dimensional solid-state NMR spectra. Magn. Reson. Chem. 40, 70-76.

Mathers, N.J., Xu, Z., 2003. Solid-state 13C NMR spectroscopy: characterization of soil organic matter under two contrasting residue management regimes in a 2-year-old pine plantation of subtropical Australia. Geoderma 114:19-31. http://dx.doi.org/10 1016/S0016-7061(02)00339-7.

Matos, E.S., Freese, D., Slazak, A., Bachmann, U., Veste, M., Hüttl, R.F., 2010. Organic-carbon and nitrogen stocks and organic-carbon fractions in soil under mixed pine and oak forest stands of different ages in NE Germany. J. Plant Nutr. Soil Sci. 173:654-661. http://dx.doi.org/10.1002/jpln.200900046.

Meier, C.L., Bowman, W.D., 2010. Chemical composition and diversity influence non-additive effects of litter mixtures on soil carbon and nitrogen cycling: implications for plant species loss. Soil Biol. Biochem. 42:1447-1454. http://dx.doi.org/10.1016/j. soilbio.2010.05.005.

Pailler, A., Vennetier, M., Torre, F., Ripert, C., Guiral, D., 2014. Forest soil microbial functional patterns and response to a drought and warming event: key role of climateplant-soil interactions at a regional scale. Soil Biol. Biochem. 70:1-4. http://dx.doi. org/10.1016/j.soilbio.2013.12.003.

Pautasso, M., Holdenrieder, O., Stenlid, J., 2005. Susceptibility to fungal pathogens of forests differing in tree diversity. In: Scherer-Lorenzen, D.M., Körner, P.D.C., Schulze, P.D.E.-D. (Eds.), Forest Diversity and Function. Ecological Studies. Springer, Berlin Heidelberg, pp. 263-289.

Peersen, O.B., Wu, X.L., Kustanovich, I., Smith, S.O., 1993. Variable-Amplitude Cross-Polarization \{MAS\} \{NMR\}. J. Magn. Reson. A 104:334-339. http://dx.doi.org/10.1006 jmra.1993.1231. 
Percival, H.J., Parfitt, R.L., Scott, N.A., 2000. Factors controlling soil carbon levels in New Zealand grasslands. Soil Sci. Soc. Am. J. 64:1623. http://dx.doi.org/10.2136/ sssaj2000.6451623x

Poca, M., Vaieretti, M.V., Cingolani, A.M., Pérez-Harguindeguy, N., 2015. Scaling-up from species to ecosystems: how close can we get to actual decomposition? Acta Oecol. 64:1-9. http://dx.doi.org/10.1016/j.actao.2015.02.005.

Polyakova, O., Billor, N., 2007. Impact of deciduous tree species on litterfall quality, decomposition rates and nutrient circulation in pine stands. For. Ecol. Manag. 253: 11-18. http://dx.doi.org/10.1016/j.foreco.2007.06.049.

Pons, A., Quézel, P., 1998. Â propos de la mise en place du climat méditerranéen. C. R. Acad. Sci. Ser. IIA Earth Planet. Sci. 327:755-760. http://dx.doi.org/10.1016/S12518050(99)80047-0.

Prescott, C.E., Grayston, S.J., 2013. Tree species influence on microbial communities in litter and soil: current knowledge and research needs. For. Ecol. Manag. 309, 19-27.

Quézel, P., Médail, F., 2004. Ecologie et biogéographie des forêts du bassin méditérranéen. Elsevier Masson, Paris.

Rodriguez-Loinaz, G., Onaindia, M., Amezaga, I., Mijangos, I., Garbisu, C., 2008. Relationship between vegetation diversity and soil functional diversity in native mixed-oak forests. Soil Biol. Biochem. 40, 49-60.

Römkens, P.F.A.M., Dolfing, J., 1998. Effect of Ca on the solubility and molecular size distribution of DOC and Cu binding in soil solution samples. Environ. Sci. Technol. 32: 363-369. http://dx.doi.org/10.1021/es970437f.

Rousk, J., Baath, E., Brookes, P.C., Lauber, C.L., Lozupone, C., Caporaso, J.G., Knight, R., Fierer N., 2010. Soil bacterial and fungal communities across a pH gradient in an arable soil. ISME J. 4, 1340-1351.

Saiya-Cork, K., Sinsabaugh, R., Zak, D., 2002. The effects of long term nitrogen deposition on extracellular enzyme activity in an Acer saccharum forest soil. Soil Biol. Biochem. 34, 1309-1315.

Sariyildiz, T., Tüfekçioğlu, A., Küçük, M., 2005. Comparison of decomposition rates of beech (Fagus orientalis Lipsky) and spruce (Picea orientalis (L.) Link) litter in pure and mixed stands of both species in Artvin, Turkey. Turk. J. Agric. For. 29, 429-438.

Schaefer, J., Stejskal, E., 1976. Carbon-13 nuclear magnetic resonance of polymers spinning at the magic angle. J. Am. Chem. Soc. 98, 1031-1032.
Scheibe, A., Steffens, C., Seven, J., Jacob, A., Hertel, D., Leuschner, C., Gleixner, G., 2015. Effects of tree identity dominate over tree diversity on the soil microbial community structure. Soil Biol. Biochem. 81:219-227. http://dx.doi.org/10.1016/j.soilbio.2014. 11.020 .

Sherman, C., Steinberger, Y., 2012. Microbial functional diversity associated with plant litter decomposition along a climatic gradient. Microb. Ecol. 64:399-415. http://dx.doi. org/10.1007/s00248-012-0037-7.

Tardif, A Shipley, B, Bloor, JM.G. Soussana, J-F, 2014. Can the biomass-ratio hypothesis predict mixed-species litter decomposition along a climatic gradient? Ann. Bot. 113: 843-850. http://dx.doi.org/10.1093/aob/mct304.

Tatoni, T., Roche, P., 1994. Comparison of old-field and forest revegetation dynamics in Provence. J. Veg. Sci. 295-302.

Van Wesemael, B., Veer, M.A.C., 1992. Soil organic matter accumulation, litter decomposition and humus forms under Mediterranean-type forests in southern Tuscany, Italy. J. Soil Sci. 43:133-144. http://dx.doi.org/10.1111/j.1365-2389.1992.tb00125.X.

Vilà, M., Vayreda, J., Comas, L., Ibáñez, J.J., Mata, T., Obón, B., 2007. Species richness and wood production: a positive association in Mediterranean forests. Ecol. Lett. 10, 241-250.

Wirth, C., 2005. Fire regime and tree diversity in boreal forests: implications for the carbon cycle. In: Scherer-Lorenzen, D.M., Körner, P.D.C., Schulze, P.D.E.-D. (Eds.), Forest Diversity and Function. Ecological Studies. Springer, Berlin Heidelberg, pp. 309-344. www.worldclim.org.

Xiao, Y., Huang, Z., Lu, X., 2015. Changes of soil labile organic carbon fractions and their relation to soil microbial characteristics in four typical wetlands of Sanjiang Plain, Northeast China. Ecol. Eng. 82:381-389. http://dx.doi.org/10.1016/j.ecoleng.2015. 05.015.

Zech, W., Ziegler, F., Kögel-Knabner, I., Haumaier, L., 1992. Advances in Humic Substances Research Humic substances distribution and transformation in forest soils. Sci. Total Environ. 117:155-174. http://dx.doi.org/10.1016/0048-9697(92)90084-6. 